JUSTYNA ZAJĄC

Warszawa

\title{
Unia Europejska wobec idei państwa palestyńskiego
}

23 września 2011 roku prezydent Autonomii Palestyńskiej Mahmud Abbas złożył na ręce Sekretarza Generalnego Organizacji Narodów Zjednoczonych Ban Ki-Moona wniosek o przyjęcie Palestyny w poczet członków tej organizacji, jako państwa istniejącego w granicach z 4 czerwca 1967 roku, ze stolicą w Jerozolimie. Wniosek ten, jak również wystąpienie Abbasa przed Zgromadzeniem Ogólnym ONZ wywołały żywą dyskusję w świecie na temat wieloletniej walki Palestyńczyków o utworzenie niepodległego państwa, ich obecnej sytuacji oraz przyszłości. Wśród społeczności międzynarodowej zarysował się wyraźny podział. Część państw, w tym Rosja i Chiny zapowiedziały poparcie wniosku, inne, jak Stany Zjednoczone - zdecydowanie mu się sprzeciwiły, a część państw przyjęła postawę ostrożną, bez wyraźnego zajmowania stanowiska. Jest niemal pewne, że Palestyna nie zostanie przyjęta do ONZ jako pełnoprawny członek, ponieważ zgodnie z Kartą Narodów Zjednoczonych do podjęcia takiej decyzji niezbędna jest zgoda wszystkich stałych członków Rady Bezpieczeństwa ${ }^{1}$. Sytuacja jest jednak nader skomplikowana; 31 października b.r. jedna z agend ONZ - UNESCO głosami 107 państw (przy 52 wstrzymujących, 14 przeciwnych, a 21 nieobecnych) poparła wniosek przyjęcia Palestyny jako pełnoprawnego członka.

Państwa Unii Europejskiej okazały się w tej sprawie głęboko podzielone. Wobec wniosku prezydenta Abbasa Unia nie była w stanie przyjąć wspólnego stanowiska. Podczas głosowania w UNESCO jedenaście państw członkowskich UE opowiedziało się za wnioskiem (Austria, Belgia, Cypr, Finlandia, Francja, Grecja, Hiszpania, Irlandia, Luksemburg, Malta, Słowenia); pięć głosowało „przeciw” (Czechy, RFN, Litwa, Holandia, Szwecja) a jedenaście wstrzymało się od głosu (Bułgaria, Dania, Estonia, Włochy, Węgry, Łotwa, Polska, Portugalia, Rumunia, Słowacja, Wielka Brytania). Uwidoczniło to brak jednolitego stanowiska państw europejskich wobec konfliktu izraelsko-palestyńskiego i koncepcji jego rozwiązania.

Celem artykułu jest nie tyle przeanalizowanie rozbieżnych interesach państw członkowskich Unii Europejskiej, co przedstawienie stanowiska Unii Europejskiej wobec idei państwa palestyńskiego, jej działań w tym zakresie oraz ich efektywności.

1 Zgodnie z art. 4 ust. 2 KNZ „Przyjęcie każdego [...] państwa do ONZ następuje w drodze decyzji Zgromadzenia Ogólnego, powziętej na zalecenie Rady Bezpieczeństwa", a art. 27 stanowi, że decyzje Rady Bezpieczeństwa we wszystkich innych sprawach niż proceduralne zapadają większością dziewięciu członków, włączając w to głosy wszystkich członków stałych. 


\section{Unia Europejska adwokatem koncepcji two-state solution}

Państwa europejskie jako jedne z pierwszych krajów spoza regionu Bliskiego Wschodu poparły ideę utworzenia niepodległego państwa palestyńskiego. W czerwcu 1980 roku w tzw. deklaracji weneckiej Wspólnota Europejska uznała, że naród palestyński musi mieć przyznaną możliwość ,pełnego zrealizowania swojego prawa do samostanowienia”, a Organizacja Wyzwolenia Palestyny (OWP) powinna być włączona do rokowań pokojowych ${ }^{2}$. Postulat ten był powtarzany przez Unię Europejską wyraźnie od lat dziewięćdziesiątych XX wieku. Powstała w 1993 roku, na mocy Traktatu z Maastricht Unia konsekwentnie podkreśla konieczność istnienia na obszarze Palestyny dwóch państw (tzw. two-state solution), tj. Państwa Izrael oraz państwa palestyńskiego. Idea ta została wyraźnie podkreślona w deklaracji berlińskiej, przyjętej przez Radę Europejską w marcu 1999 roku, a trzy lata później, w czerwcu 2002 roku, na szczycie w Sewilli, Rada Europejska zaapelowała o szybkie zwołanie konferencji międzynarodowej, która zajęłaby się politycznymi i ekonomicznymi sprawami rozwiązania konfliktu arabsko-izraelskiego oraz kwestiami odnoszącymi się do bezpieczeństwa, tak by osiagnąc ostateczne porozumienie i doprowadzić do zrealizowania zasady istnienia dwóch państw.

Zgodnie z koncepcją konieczności utworzenia niepodległego państwa palestyńskiego Unia Europejska niezmiennie stoi na stanowisku, że Izrael powinien wycofać się z ziem zajętych podczas wojny sześciodniowej 1967 roku, z niewielkimi modyfikacjami, jeśli są one niezbędne. Zmiany te muszą być zgodne z zapisami rezolucji Rady Bezpieczeństwa ONZ nr 242, 338, 1397, 1402 i 1515 oraz z poszanowaniem zasad przyjętych w bliskowschodnim procesie pokojowym, rozpoczętym Konferencją Madrycką jesienią 1991 roku. UE wyraźnie podkreśla, że polityka Izraela budowania osiedli żydowskich na Zachodnim Brzegu Jordanu, we Wschodniej Jerozolimie i Strefie Gazy jest nielegalna z punktu widzenia prawa międzynarodowego i niejednokrotnie apelowała do Izraela o zaprzestanie tych działań, a także sprzeciwiała się budowie muru odgradzającego Autonomię Palestyńską od Izraela.

Co istotne jednak Unia Europejska nie odnosi się do postulatów utworzenia stolicy państwa palestyńskiego we Wschodniej Jerozolimie, ani też nie proponuje żadnych rozwiązań w kwestii uchodźców palestyńskich. Uznaje, że sprawy te powinny zostać uregulowane podczas negocjacji pokojowych izraelsko-palestyńskich i deklaruje, że będzie szanować osiągnięte przez obie strony porozumienie ${ }^{3}$.

\section{Unia Europejska wspóltwórcą palestyńskich struktur państwowych}

Stojąc na stanowisku, że tylko niepodległe, demokratyczne i zdolne do funkcjonowania państwo palestyńskie może stanowić bezpieczne sąsiedztwo dla Izraela, Unia Europejska wspiera proces jego tworzenia, w szczególności poprzez:

2 Déclaration du Conseil: Proche-Orient-Moyen-Orient (Venise, $12-13$ juin 1980), Documents d'Actualité Internationale, no 29-30, 21-28 juillet 1980, s. 594-595.

3 Szerzej zob. J. Zając, Role Unii Europejskiej w regionie Afryki Pótnocnej i Bliskiego Wschodu, WUW, Warszawa 2010, s. $104 \mathrm{i}$ in. 
- budowanie instytucji państwowych i systemu dobrego rządzenia, w tym tworzenie nowoczesnych i demokratycznych sił policyjnych oraz stanowienie sprawnego systemu prawnego;

- stabilizowanie sektora palestyńskich finansów publicznych;

- rozwijanie palestyńskiej gospodarki, w tym sektora prywatnego ${ }^{4}$.

\section{Monitorowanie wyborów do władz Autonomii Palestyńskiej}

Opierając swoje funkcjonowanie na zasadach demokratycznych i rządach prawa Unia Europejska podjęła szereg działań promujących te wartości w tworzeniu palestyńskich struktur państwowych. Silnie zaangażowała się w monitorowanie wyborów, jakie przeprowadzano w Autonomii Palestyńskiej. Na mocy wspólnych działań, przyjętych przez 19 kwietnia 1994 roku oraz 25 września 1995 roku Rada Unii utworzyła Europejski Zespół Wyborczy, którego zadaniem było kierowanie grupą 300 obserwatorów wysłanych do nadzorowania wyborów do Rady Palestyńskiej, organizowanych zgodnie z postanowieniami Deklaracji Zasad z września 1993 roku. Unia wspomagała również przeprowadzenie kolejnych wyborów (w 2005 i 2006 roku), wydając na ten cel $20 \mathrm{mln}$ euro ${ }^{5} .8$ grudnia 2004 roku, po zaproszeniu przez Centralną Palestyńską Komisję Wyborczą wysłała na Zachodni Brzeg oraz do Strefy Gazy Misję Obserwacyjną do spraw Wyborów. W sumie liczyła ona 237 osób z 19 państw członkowskich UE, wspomaganych przez ekspertów z Kanady, Norwegii i Szwajcarii. Na czele zespołu stanął były premier Francji, członek Parlamentu Europejskiego - Michel Rocard. Misja miała na celu wspieranie i monitorowanie procesu powszechnych wyborów prezydenckich w Autonomii Palestyńskiej, przeprowadzanych po śmierci Jasira Arafata, 9 stycznia 2005 roku. Obserwatorzy pozytywnie ocenili wkład władz palestyńskich w przeprowadzenie tych wyborów zgodnie ze standardami międzynarodowymi. Podkreślili jednak, że trwająca okupacja terytoriów palestyńskich, przemoc i ograniczenia swobody przemieszczania się sprawiły, że wybory te nie były w pełni wolne ${ }^{6}$. Podobne wnioski zostały przedstawione przez obserwatorów wyborów do Palestyńskiej Rady Legislacyjnej, które odbyły się 25 stycznia 2006 roku. Misja UE, której przewodniczyła Belgijka - Véronique de Kayser (członek Parlamentu Europejskiego), rozpoczęła się 13 grudnia 2005 roku i trwała do 13 lutego 2006 roku. W sumie liczyła 190 osób z 23 państw członkowskich UE oraz Norwegii, Szwajcarii i Rumunii ${ }^{7}$. Pomimo uchybień i niedociągnięć nie zakwestionowano demokratyczności wyborów. Jednak znaczna część społeczności międzynarodowej, w tym także Unia Europejska, szybko wycofała

${ }^{4}$ Statebuilding for Peace in the Middle East: an EU Action Strategy. Joint Paper by EU High Representative Javier Solana and EU Commissioner for External Relations Benita Ferrero-Waldner, November 2007, s. 378.

5 European Commission Technical Assistance Office for the West Bank and Gaza Strip, http://www.delwbg.ec.europa.eu (czerwiec 2009 r.).

6 West Bank and Gaza. Presidential Elections, 9 January 2005, „European Union Election Observation Mission. Final Report", http://ec.europa.eu (czerwiec 2009 r.).

7 West Bank and Gaza Strip. Palestinian Legislative Council Elections, 25 January 2006, „European Union Election Observation Mission. Final Report", http://ec.europa.eu (czerwiec 2009 r.). 
swoje uznanie dla rządu, stworzonego przez Hamas, który uzyskał największą liczbę głosów (58\%). Jak podkreślił Wysoki Przedstawiciel do spraw WPZiB Javier Solana, UE nie mogła uznawać rządu, który nie wyrzekł się przemocy jako metody rozwiązania konfliktu arabsko-izraelskiego, nie uznał Państwa Izraela i nie przyjął osiagnniętych porozumień pokojowych oraz wynikających z nich zobowiązań ${ }^{8}$.

\section{Wspieranie wymiaru sprawiedliwości i służb porządku publicznego}

Od 2003 roku Unia Europejska bierze również aktywny udział w tworzeniu systemu wymiaru sprawiedliwości i służb porządku publicznego - jednego z głównych filarów każdego państwa. W tym celu utworzyła program „Wzmacnianie Systemu Sądownictwa”, w ramach którego, w grudniu 2005 roku, uruchomiono projekt „Sayeda”. Jego zadaniem jest szkolenie sędziów, prokuratorów oraz pozostałego personelu, pracującego w instytucjach sądowych, a także rozwój Palestyńskiego Instytutu Sądownictwa. Dodatkowo Autonomia Palestyńska uczestniczy w programie regionalnym finansowanym przez Unię Europejską (Euromed Justice Programme). Jego głównym celem jest organizowanie szkoleń dla prawników. W latach 2004-2008 Unia przekazała na wzmacnianie palestyńskiego wymiaru sprawiedliwości $8,5 \mathrm{mln}$ euro, z czego: $3,75 \mathrm{mln}$ euro na pomoc techniczną; $2,4 \mathrm{mln}$ euro na wyposażenie i infrastrukturę; $2 \mathrm{mln}$ euro na projekt regionalny „Euromed” oraz 350 tysięcy euro na tworzenie banku danych ${ }^{9}$.

Unia Europejska wspiera także proces tworzenia policji palestyńskiej. W kilka miesięcy po podpisaniu pierwszego izraelsko-palestyńskiego porozumienia pokojowego, tzw. Układu z Oslo I (13 września 1993 roku) przyjęła, 19 kwietnia 1994 roku wspólne działanie, które zakładało wspieranie tworzenia palestyńskich sił policyjnych. Działania te były intensyfikowane wraz z zacieśnianiem współpracy Unii Europejskiej w wymiarze Europejskiej Polityki Bezpieczeństwa i Obrony (EPBiO). W styczniu 2005 roku, Rada UE na mocy wspólnego działania utworzyła, w ramach biura Specjalnego Przedstawiciela UE do spraw bliskowschodniego procesu pokojowego - Marca Otte, Biuro Koordynacyjne dla Wspierania Palestyńskiej Policji (EU COPPS). Określono, że jego celem jest doradzanie kierownictwu policji palestyńskiej i ministrowi spraw wewnętrznych. Od 1 stycznia 2006 roku biuro to przybrało formę misji prowadzonej w ramach Europejskiej Polityki Bezpieczeństwa i Obrony (EUPOL-COPPS), której za główny cel uznano działalność na rzecz wzmocnienia porządku prawnego i poprawy bezpieczeństwa na terytoriach palestyńskich. Misja została rozmieszczona w Ramallah i Gazie. Jej liczebność stopniowo wzrasta. Początkowo, w 2006 roku liczyła 13-15 osób, w 2009 roku - 41 osób z państw członkowskich UE, Norwegii i Kanady oraz 16 Palestyńczyków, a w 2011 roku - 53 osoby - personelu UE oraz

8 Middle East Peace Process: Speech by Javier Solana, EU High Representative for the Common Foreign and Security Policy appearance before the European Parliament, Strasbourg, 5 April 2006, http://www.consilium.europa.eu/solana (czerwiec 2009 r.).

9 Laying the Foundations for a Viable and Democratic State: Empowering the Judicial System, „European Commission Technical Assistance Office for the West Bank and Gaza Strip”, http://www.delwbg.ec.europa.eu (listopad 2011 r.). 
36 Palestyńczyków. Misja ta posiada dwa główne cele działania: 1) wspieranie policji palestyńskiej (infrastruktura, logistyka, komputery, wyposażenie, szkolenia); 2) promowanie i implementowanie rządów prawa. W latach 2008-2010 Unia Europejska za priorytety misji uznała usprawnienie: procedur śledczych, technologii informacyjnej i komunikowania, infrastruktury i logistyki policyjnej, systemu sprawiedliwości ${ }^{10}$.

Ważną sferą działalności UE jest również zbudowanie systemu łączności w policji, poprzez stworzenie elektronicznej sieci informacyjnej, rozbudowę sieci telefonicznej oraz systemu komunikowania radiowego, a także wyposażenie i szkolenie policjantów, pracujących w wydziale drogowym oraz pilnujących porządku publicznego.

Oprócz Misji EUPOL COPPS Unia Europejska ustanowiła również misję monitorowania ruchu w punkcie granicznym w Rafah, na granicy Strefy Gazy i Egiptu (EU BAM Rafah). Decyzja w tej sprawie została podjęta na mocy wspólnego działania Rady UE z 12 grudnia 2005 roku. Była ona ściśle związana z porozumieniem o ruchu granicznym w Strefie Gazy, podpisanym 15 listopada 2005 roku przez Izrael i Autonomię Palestyńską ${ }^{11}$. Misja służyła monitorowaniu i kontrolowaniu właściwego funkcjonowania przejścia granicznego i legalności jego przekraczania oraz ułatwianiu współpracy oficerów palestyńskich i izraelskich, a docelowo miało służyć stopniowemu wzrostowi zaufania między nimi. Jednak po wygranych wyborach parlamentarnych przez Hamas w styczniu 2006 roku i walkach wewnętrznych wśród Palestyńczyków przejście graniczne w Rafah, w czerwcu 2007 roku, zostało zamknięte. Działalność EU BAM Rafah został zawieszona, a liczebność misji mocno zredukowana. Pozostaje ona jednak w gotowości operacyjnej, by móc wznowić swoją działalność, jeśli okoliczności na to pozwolą. Decyzja w tej sprawie zależy jednak od porozumienia między Izraelem, Autonomią Palestyńską i Egiptem.

Unia Europejska wspierała również władze Autonomii Palestyńskiej w zwalczaniu terroryzmu na jej terytorium. Na mocy wspólnego działania, przyjętego 29 kwietnia 1997 roku, został utworzony Europejsko-Palestyński Stały Komitet Bezpieczeństwa. Głównym jego celem było wzmocnienie zdolności władz palestyńskich w zakresie przeciwdziałania terroryzmowi. Program przewidywał szkolenie personelu w zakresie bezpieczeństwa oraz doszkalanie komórek policyjnych. Rada Unii przyjęła jednocześnie, że program współpracy zostanie zawieszony, jeśli Autonomia Palestyńska: 1) nie

${ }^{10}$ EU Police Mission in the Palestinian Territories (EEEUPOL COPPS), http://ue.eu.int (listopad 2011 r.). Zob. też: J. Zając, op. cit., s. 143 i n.; szerzej nt. operacji Unii Europejskiej zob. R. Zięba, Wspólna Polityka Zagraniczna i Bezpieczeństwa Unii Europejskiej, WAiP, Warszawa 2007; Misje cywilne Unii Europejskiej, red. B. Przybylska-Maszner, Wydawnictwo WNPiD, Poznań 2010.

11 Po całkowitym wycofaniu się wojsk izraelskich ze Strefy Gazy strony uzgodniły otwarcie przejść granicznych w celu ułatwienia przypływu osób i towarów, jednak po spełnieniu przez stronę palestyńską odpowiednich warunków. Zgodziły się, aby implementacja porozumienia była wspierana przez Specjalnego Wysłannika Kwartetu Bliskowschodniego do spraw Wycofania i/lub Koordynatora USA do spraw Bezpieczeństwa. Jednocześnie podjęły decyzję, aby Unia Europejska wsparła stronę palestyńską w organizowaniu służb granicznych i celnych na przejściu granicznym między Strefą Gazą a Egiptem - w Rafah. W listach do Komisarz do spraw Zewnętrznych wystosowanych 20 i 23 listopada 2005 roku kolejno władze Autonomii Palestyńskiej oraz Izraela zaprosiły UE do ustanowienia misji wspierającej Palestyńczyków na przejściu granicznym w Rafah. Zob. Agreement on Movement and Access, 15 November 2005 oraz Agreed Principles for Rafah Crossing, 15 November 2005, „Israeli Ministry of Foreign Affairs”, http://www.mfa.gov.il (czerwiec 2009 r.). 
będzie w pełni współpracować w jego implementacji; 2) nie wdroży środków ochrony praw człowieka, niezbędnych przy realizacji programu; 3) nie umożliwi UE dokonywania okresowych przeglądów wyników implementacji programu. Do kontroli i pomocy przy wprowadzaniu programu w życie Unia Europejska mianowała jako swojego przedstawiciela Nilsa Erikssona. Jednak jego mandat wygasł z dniem 31 maja 2002 roku, a program współpracy z Autonomią Palestyńską w zwalczaniu terroryzmu nie został przedłużony.

\section{Wspieranie sektora finansów publicznych}

Unia Europejska wspiera również władze Autonomii Palestyńskiej w tworzeniu sprawnie funkcjonującego sektora finansów publicznych. Od 1995 roku zapewniała szkolenia w zakresie audytu wewnętrznego, doradztwa w zakresie zarządzania i kontroli audytu w sektorze finansów publicznych. Przeszkoliła około 90 urzędników palestyńskich, co umożliwiło wprowadzenie regulacji prawnych i stworzenie palestyńskiej kontroli wewnętrznej. W latach 2000-2006 przekazała władzom Autonomii Palestyńskiej na reformę zarządzania finansami publicznymi $6,6 \mathrm{mln}$ euro, a na usprawnienie systemu przychodów $6 \mathrm{mln}$ euro. Dodatkowo palestyńskiemu Ministerstwu Finansów udzieliła wsparcia finansowego w wysokości $5 \mathrm{mln}$ euro na stworzenie systemu komputerowego, który ułatwi zarządzanie przychodami z podatków. Wsparła również finansowo, w wysokości 2,2 mln euro, Palestyńskie Biuro Statystyczne w tworzeniu przez nie systemu danych statystycznych ${ }^{12}$. Po wygranej w wyborach parlamentarnych w styczniu 2006 roku partii Hamas Unia Europejska zawiesiła pomoc finansową dla nowo utworzonego rządu palestyńskiego. Jednak w lutym 2007 roku, po ukształtowaniu palestyńskiego rządu jedności narodowej (Hamas i Al. Fatah), który podporządkował się zaleceniom Kwartetu Bliskowschodniego i dał dowody woli przejrzystego zarządzania finansami publicznymi, pomoc Komisji Europejskiej została wznowiona. Rząd ten nie przetrwał jednak długo. Unia Europejska kontynuuje współpracę z gabinetem tworzonym przez Al. Fatah i jego zwolenników, działającym na Zachodnim Brzegu Jordanu.

\section{Unia Europejska największym donatorem pomocy finansowej dla Palestyńczyków}

Unia Europejska jest największym donatorem pomocy finansowej dla Palestyńczyków. Po raz pierwszy Wspólnota Europejska wsparła ten naród w 1971 roku, przekazując fundusze do Agencji NZ do spraw Pomocy Uchodźcom Palestyńskim na Bliskim Wschodzie - UNRWA. Od tego czasu regularnie i w coraz większym stopniu wspiera finansowo społeczeństwo palestyńskie. W latach 1993-2010 UE przekazała na pomoc dla Palestyńczyków ponad 10 miliardów euro. Kwota ta została przeznaczona

12 European Commission Technical Assistance Office for the West Bank and Gaza Strip, http://www.delwbg.ec.europa.eu (czerwiec 2009 r.). 
m.in. na tworzenie instytucji państwowych, w tym reformy finansów publicznych, budowę infrastruktury państwowej, pomoc uchodźcom palestyńskich, pomoc żywnościowa, wspieranie sektora ochrony zdrowia, wsparcie społeczeństwa obywatelskiego.

Pomoc UE dla władz i społeczeństw palestyńskiego przybierała różne formy. Do 2006 roku gros pomocy było kierowane bezpośrednio do władz palestyńskich i de facto przez wiele lat było bezwarunkowe. UE udzielała pomocy bez rzeczywistego egzekwowania implementacji uzgodnionych warunków. Al.-Fatah, który sprawował władzę do początków 2006 roku okazał się ugrupowaniem silnie skorumpowanym. Przekazywane przez Unię Europejską fundusze nie były wydawane w sposób przejrzysty. Dziwi w tym kontekście stanowisko Unii Europejskiej, która nie stworzyła mechanizmu kontroli i nie wymagała przejrzystych procedur wydatkowania funduszy, jako warunku dalszego udzielania pomocy finansowej. Nie bezzasadne są opinie, że znaczna część pomocy została przekazana przez władze palestyńskie na prywatne konta przywódców i członków Al.-Fatah. Dopiero od 2002 roku Unia Europejska, udzielając pomocy finansowej przywiązywała większą wagę do uzależniania jej od przeprowadzanych przez władze Autonomii Palestyńskiej reform ${ }^{13}$. Zmiana ta była ściśle związana z Intifadą II oraz polityką administracji George’a W. Busha wobec władz Autonomii Palestyńskiej. Częste zamachy terrorystyczne w Izraelu, organizowane przez Palestyńczyków oraz obwinianie za taką sytuację Jasira Arafata przez Waszyngton i Tel Aviv, zmusiły Unię Europejską do zwiększenia wymogów wobec Autonomii Palestyńskiej ${ }^{14}$. Zaostrzająca się na Bliskim Wschodzie sytuacja i niechęć wielu Palestyńczyków do Al.-Fatahu spowodował, że w styczniu 2006 roku wybory parlamentarne wygrał Hamas, a Unia Europejska, uznająca to ugrupowanie za terrorystyczne nie uznała tworzonego przez niego rządu i w czerwcu 2006 roku we współpracy z Bankiem Światowym, na wniosek Kwartetu Bliskowschodniego utworzyła nowy mechanizm przekazywania funduszy dla Palestyńczyków - Tymczasowy Mechanizm Międzynarodowy - TIM. Jego celem było bezpośrednie dostarczanie pomocy dla ludności palestyńskiej, z pominięciem władz Autonomii Palestyńskiej. Pomoc ta była udzielana przez Komisję Europejską, państwa członkowskie UE i innych donatorów. W ramach mechanizmu TIM w latach 2006-2007 Komisja Europejska przekazała Palestyńczykom 455,5 mln euro (w 2006 roku - 107,5 mln euro; w 2007 roku - 348 mln euro) ${ }^{15}$.

Obok funduszy przekazanych w ramach Tymczasowego Mechanizmu Międzynarodowego Unia Europejska przeznaczyła dodatkowo $200 \mathrm{mln}$ euro na inne programy pomocowe dla Palestyńczyków. Objęły one m.in.: koszty leczenia, wsparcia psychologicznego i socjalnego, dostawy wody pitnej, budowy schronisk dla ludności, propagowanie zatrudnienia. Działalność ta była prowadzona we współpracy z agencjami ONZ, organizacjami pozarządowymi i ruchem Czerwonego Krzyża i Półksiężyca.

13 Szerzej zob. A. Le More, Killing with Kindness: Funding the Demise of a Palestinian State, „International Affairs”, vol. 81, no. 5, October 2005, s. 981-999; N. Roberts, Hard Lessons from Oslo: foreign aid, the mistakes of the 1990s, w: Aid, diplomacy and facts on the ground: the case of Palestine, eds. M. Keating, A. Le More, R. Lowe, Chatham Mouse, London 2005, s. 19, 24.

${ }_{14}$ D. Pioppi, N. Tocci, K. Karam, Domestic Politics and Conflict in the Cases of Israel, Palestine and Lebanon, „EuroMeSCo Paper”, no. 53, October 2006, s. 21.

15 Temporary International Mechanism - TIM, 18 January 2008, http://ec.europa.eu/external_relations/occupied_palestinian_territory/tim/factsheet_tim_en.pdf (październik 2011.). 
Międzynarodowa pomoc finansowa dla Palestyńczyków, w ramach Tymczasowego Mechanizmu Międzynarodowego (2006-2007)

\begin{tabular}{|c|c|c|c|c|c|c|c|c|c|c|c|c|c|c|c|c|c|c|c|c|c|}
\hline 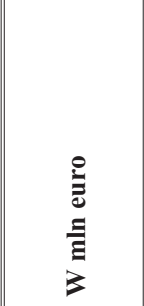 & 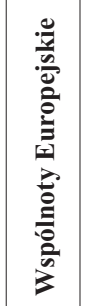 & 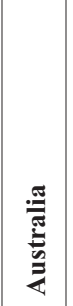 & 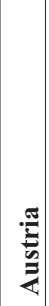 & 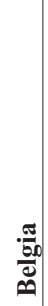 & 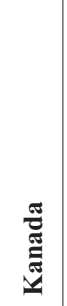 & 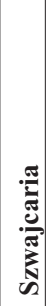 & $\underset{\underline{I}}{\mathbf{Z}}$ & 竎 & 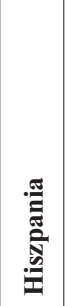 & 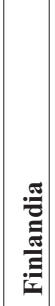 & 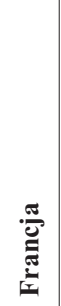 & 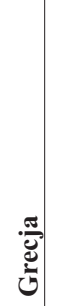 & 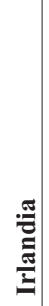 & $\frac{\vec{e}}{0}$ & 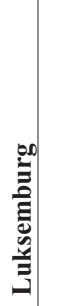 & $\frac{\stackrel{\pi}{\frac{\pi}{\pi}}}{\sum_{\Sigma}^{\pi}}$ & 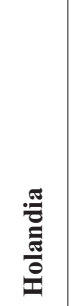 & 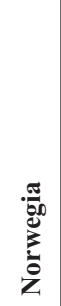 & 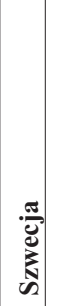 & 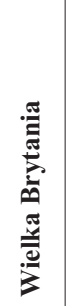 & Uू \\
\hline ransza I & 15,0 & 2,55 & 1,0 & 2,5 & - & 1,5 & - & - & 15,0 & - & 3,0 & \begin{tabular}{|l|l}
- \\
\end{tabular} & - & $2,3$. & - & - & - & 2,6 & 4,9 & 8,9 & 59,25 \\
\hline ransza II & 31,0 & - & - & - & - & - & - & - & - & - & - & - & - & - & - & - & - & - & - & - & 131,0 \\
\hline ansza III & 309,5 & - & - & - & 5,65 & - & 40,0 & 0,8 & 10,0 & 1,0 & 11,5 & \begin{tabular}{|l|l|}
0,2 & 2 \\
\end{tabular} & 2,0 & \begin{tabular}{l|l}
- & 2
\end{tabular} & \begin{tabular}{l|l}
2,2 & 0
\end{tabular} & \begin{tabular}{l|l}
, 03 & 1 \\
\end{tabular} & 18,87 & 5,95 & \begin{tabular}{|l|l|}
4,8 & 1 \\
\end{tabular} & 13,19 & 425,69 \\
\hline
\end{tabular}

Źródło: Temporary International Mechanism: Overall Implementation Process, 18 January 2008, http://ec.europa.eu/external_relations (listopad 2011 r.).

W lutym 2008 roku Unia Europejska podjęła decyzję o zastapieniu TIM programem PEGASE (Mécanisme Palestino-Européen de Gestion et d'Aide Socio-Economique). Jest to mechanizm, poprzez który Komisja Europejska udziela wsparcia dla Palestyńskiego Planu Reform i Rozwoju, zaprezentowanego w grudniu 2007 roku przez premiera Autonomii Palestyńskiej Salama Fayyada. Program PEGASE został uruchomiony w następstwie konferencji międzynarodowej, która odbyła się 17 grudnia 2007 roku w Paryżu. Jest on przedmiotowo szerszy od Tymczasowego Mechanizmu Międzynarodowego (TIM) ${ }^{16}$. Z jego funduszy Unia Europejska wspiera cztery reformy: instytucji państwowych, sektora społecznego, gospodarczego sektora prywatnego, infrastruktury publicznej. Od lutego 2008 roku w ramach programu PEGASE Palestyńczykom zostało przekazanych około miliard euro.

Przeznaczenie pomocy międzynarodowej dla Palestyńczyków w latach 2008-2010

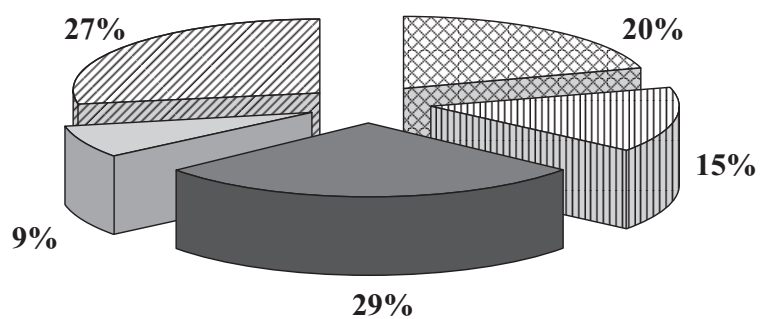

Wsparcie budżetu Autonomii Palestyńskiej

向 Pomoc humanitarna

Pomoc na realizowanie projektów prywatnych

Pomoc techniczna, szkolenia

Inne cele

Źródło: International Donors' Conference for the Palestinian State: Pledges Recap, 22 January 2008, France Diplomatie Ministére des Affaires Étrangères et Européennes, http://www.diplomatie.gouvr.fr (listopad 2011 r.).

Pomoc Unii Europejskiej przybiera też inne formy działania. W grudniu 2005 roku Komisja Europejska oraz Europejski Bank Inwestycyjny podpisały z Autonomią Pale-

16 PEGASE Information Sheet, http://ec.europa.eu/external_relations/occupied_palestinian_territory/tim/pegase_en.pdf (październik 2011 r.). 
styńską porozumienie o utworzeniu Europejsko-Palestyńskiego Kredytowego Funduszu Gwarancyjnego, kierowanego przez Niemiecki Bank Rozwoju (German Development Bank - KfW). Donatorzy zgodzili się na przekazanie do funduszu $29 \mathrm{mln}$ euro (Komisja Europejska - 14 mln euro, Europejski Bank Inwestycyjny - 10 mln euro, KfW - 5 mln euro), jako zabezpieczenie dla banków lokalnych, które udzielają pożyczek małym i średnim przedsiębiorstwom, niespełniającym wymogów kredytowych. Od września 2006 roku do grudnia 2008 roku fundusz zaakceptował 667 pożyczek gwarantowanych. Wszystkie z nich zostały spłacone zgodnie z umową. Najwięcej pożyczek zostało udzielonych przedsiębiorstwom działającym w okręgu północnym, obejmującym Nablus, Dżenin, Tulkarm i Kaliję (290 pożyczek), rozwijających swoją działalność w sektorze handlowym (373 pożyczek) ${ }^{17}$.

Liczba pożyczek dla przedsiębiorstw palestyńskich, z podziałem na okręgi

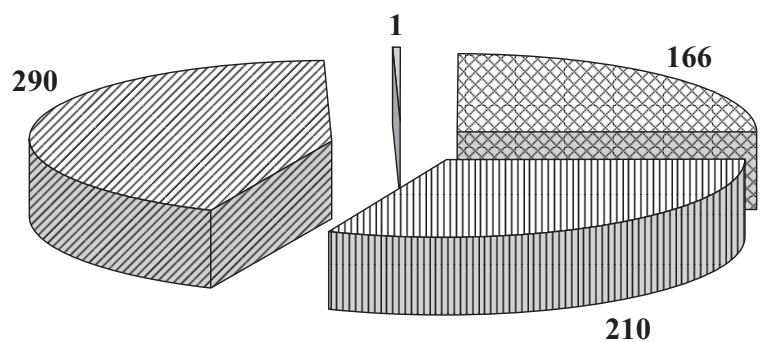

图 Okręg południowy (Hebron, Betlejem)

而 Okręg środkowy (Ramallah, Wschodnia Jerozolima, Al. Ram, Benthany, Jerycho

$\bigotimes$ Okręg północny (Nablus, Dżenin, Tulkarm, Kalkija)

Strefa Gazy

Źródło: General Statistics Report. Third Newsletter, 31 December 2008, European Palestinian Credit Guarantee Fund, http://www.cfg-palestine.com (listopad 2011 r.).

Sektory działania małych i średnich przedsiębiorstw, które otrzymały pożyczki gwarantowane przez Europejsko-Palestyński Kredytowy Fundusz Gwarancyjny

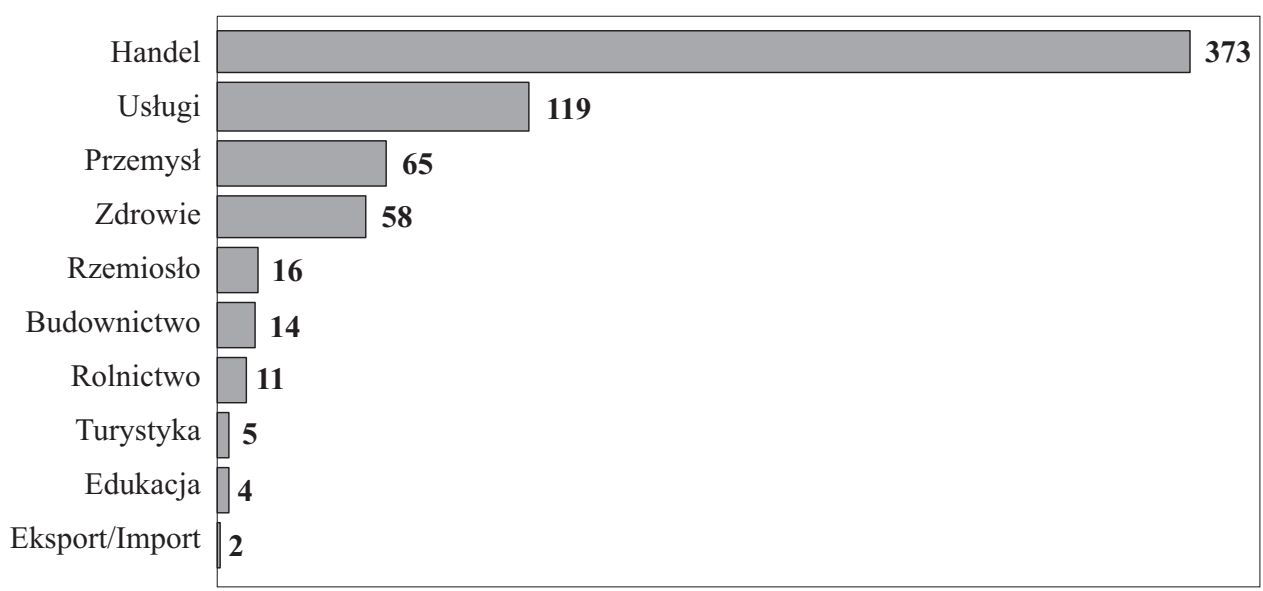

Źródło: General Statistics Report. Third Newsletter, 31 December 2008, European Palestinian Credit Guarantee Fund, http://www.cfg-palestine.com (listopad 2011 r.).

17 General Statistics Report. Third Newsletter, 31 December 2008, European Palestinian Credit Guarantee Fund, http://www.cfg-palestine.com (październik 2011 r.). 
Jednym z najnowszych program UE wspierających Palestyńczyków, jest utworzony we współpracy z rządem niemieckim w końcu października 2011 roku tzw. program TVET (Technical and Vocational Education and Ttraining). Pomoc w wysokości 4 milionów euro ma przyczynić się do zwiększenia poziomu zatrudnienia wśród osób młodych w regionie Betlejem, Nablusu i Hebronu ${ }^{18}$.

Oprócz przedstawionych powyżej programów wsparcia finansowego Unia Europejska przekazuje również fundusze dla uchodźców palestyńskich w Libanie, Syrii i Jordanii. Podstawowe ich potrzeby obejmują: zapewnienie schronienia, opieki zdrowotnej, psychospołecznego wsparcia, dostępu do wody i instalacji oczyszczających oraz ochronę niezarejestrowanych uchodźców. Wspólnota Europejska jest największym donatorem Agencji NZ do spraw Pomocy Uchodźcom Palestyńskim na Bliskim Wschodzie (UNRWA). W latach 2003-2006 Unia Europejska oraz jej państwa członkowskie przekazały na ten fundusz $246 \mathrm{mln}$ euro. W latach 2007-2010 kwota ta wyniosła ponad 250 mln euro. Podobną kwotę UE zadeklarowała na lata 2011-2013.

\section{Ocena i perspektywy działań Unii Europejskiej wobec Palestyny}

Dotychczasowe działania Unii Europejskiej wobec Palestyny trudno poddać jednoznacznej ocenie. Z jednej strony należy docenić fakt, iż Unia Europejska w dużej mierze wspiera politycznie i ekonomicznie Palestyńczyków, z drugiej strony jednak nie można oprzeć się wrażeniu, że jej polityka jest niespójna, a niekiedy również wewnętrznie sprzeczna.

Na pozytywną ocenę zasługuje niewątpliwie fakt, że UE jako jeden z pierwszych uczestników stosunków międzynarodowych, spoza regionu Bliskiego Wschodu, opowiedziała się za utworzeniem niepodległego państwa palestyńskiego i międzynarodowym uznaniem Organizacji Wyzwolenia Palestyny jako reprezentanta narodu palestyńskiego. Było to w 1980 roku, a więc w okresie kiedy ani Izrael, ani silnie wspierające go Stany Zjednoczone takich rozwiązań nie dopuszczali. UE również w największym stopniu wspiera proces tworzenia państwa palestyńskiego; pomaga kształtować system polityczny i sprawne zarządzanie, budowę infrastruktury państwowej oraz sektorów publicznych, wspiera tworzenie służb bezpieczeństwa wewnętrznego i porządku publicznego, pomaga rozwijać prywatne inicjatywy w zakresie gospodarki i handlu, a także na bieżąco udziela pomocy humanitarnej dla ludności palestyńskiej, dotkniętej skutkami konfliktu. UE jest największym donatorem pomocy finansowej dla Palestyńczyków. Pomoc ta w latach 1993-2010 wyniosła ponad 10 miliardów euro.

Jednocześnie polityka Unii Europejskiej jest jednak niespójna. UE popiera utworzenie państwa palestyńskiego, ale nie była w stanie zająć wspólnego stanowiska wobec wniosku prezydenta M. Abbasa złożonego we wrześniu 2010 roku w ONZ. Systematycznie i konsekwentnie UE podkreśla konieczność wycofania się Izraela z ziem zajętych podczas wojny sześciodniowej 1967 roku oraz zlikwidowania istniejących na tych obszarach osiedli żydowskich, przestrzegania zasad prawa międzynarodowego, powstrzymywania się stron od użycia siły i przemocy, jednak niestosowanie

$18 \mathrm{http} / / /$ eeas.europa.eu/. 
się stron do tych apeli nie pociaga za sobą konkretnych działań. UE często krytykuje Izrael za jego posunięcia względem Palestyńczyków, a jednocześnie utrzymuje i dynamicznie rozwija $\mathrm{z}$ tym państwem stosunki w różnych dziedzinach. Izrael znajduje się w pierwszej trzydziestce wśród partnerów handlowych UE, co biorąc pod uwagę jego wielość należy uznać za pozycję bardzo dobrą. Dodatkowo wobec wszystkich umów z Unią Europejską Izrael przyjmuje interpretację, że integralną częścią jego terytorium są ziemie zajęte podczas wojny sześciodniowej 1967 roku, co nie spotyka się z negatywną reakcją UE ${ }^{19}$.

Unia Europejska głosi hasła koniecznej demokratyzacji Autonomii Palestyńskiej, ale nie uznała, wygranego w 2006 roku, w demokratycznych wyborach rządu Hamasu. Przez długi czas nie reagowała też na niedemokratyczne posunięcia władz palestyńskich i brak przejrzystości wydatkowania przekazywanych przez siebie funduszy. Dopiero od 2002 roku zaczęła w większym stopniu uzależniać przekazywanie pomocy finansowej od reform przeprowadzanych przez władze Autonomii Palestyńskiej ${ }^{20}$.

Niekonsekwentne postępowanie Unii Europejskiej sprawia, że ma ona opinię aktora niewiarygodnego i nieskutecznego, któremu brakuje koherentnej polityki. W konsekwencji jest postrzegana nie jako podmiot samodzielny, ale wspomagający Stany Zjednoczone, które posiadają realne możliwości oddziaływania. W opinii państw arabskich USA występują w roli „złego policjanta”, a UE stara się odgrywać rolę „,dobrego policjanta" ${ }^{21}$. Niewiarygodność Unii Europejskiej w oczach Arabów wzmacniają konotacje historyczne, a także brak wiary w jej realne możliwości działania, wynikające z jej specyfiki jako aktora międzynarodowego.

Z pewnością międzyrządowy charakter wspólnej polityki zagranicznej i bezpieczeństwa Unii Europejskiej zdecydowanie utrudnia jej prowadzanie skutecznej polityki wobec Palestyny. Zajęcie wspólnego stanowiska wymaga bowiem zgody wszystkich członków Unii Europejskiej, a w najlepszym razie zdecydowanej ich większości. W przypadku konfliktu arabsko-izraelskiego i spraw z nim związanych wypracowanie wspólnego stanowiska bywa jednak bardzo trudne, ze względu na rozbieżne interesy państw członkowskich, czego dowodem było głosowanie sprawy palestyńskiej w UNESCO w październiku 2010 roku. Różne uwarunkowania natury historycznej, politycznej, ekonomicznej i społecznej tworzą skomplikowany obraz rzeczywistości, w której decydenci Unii Europejskiej i państw członkowskich muszą podejmować decyzje.

Istnieje również sprzeczność między tożsamością międzynarodową Unii Europejskiej a interesami jej państw członkowskich. Zbudowana na takich wartościach jak:

19 D. Pioppi, N. Tocci, K. Karam, Domestic Politics and Conflict in the Casus of Israel, Palestine and Lebanon, „EuroMeSCo Paper”, no. 53, October 2006, s. 31.

${ }_{20}$ Zmiana ta była ściśle związana z Intifadą II i polityką administracji George’a W. Busha wobec władz Autonomii Palestyńskiej. Zdecydowane obwinianie Jasira Arafata i Palestyńczyków za załamanie się procesu pokojowego zmusiło Unię Europejską do zwiększenia wymogów w stosunku do Autonomii Palestyńskiej. Pioppi, Tocci, Karam, op. cit., s. 21.

21 Y. Sayigh, Security Sector reform in the Arab Region, Challenges to Developing an Indigenous Agenda, Arab Reform Initiative, „Thematic Papers”, no. 2, December 2007; Securing the Future: Europe's Agenda for a More Peaceful Neighborhood, „Discussion Paper for the XI Kronberg Talks”, Europe and Middle East”, Bertelsmnn Stiftung, January 17-19, 2009. 
godność ludzka, wolność, demokracja, równość, rządy prawa, poszanowanie praw człowieka, solidarność społeczna, zrównoważony rozwój Unia Europejska kieruje się nimi w swojej polityce zewnętrznej. We współpracy z innymi państwami świata UE podejmuje, obok kwestii gospodarczych, także problematykę demokracji, dobrego rządzenia, przestrzegania praw człowieka, kształtowania stosunków poprzez współpracę, ochronę środowiska. Stara się je wdrażać, instytucjonalizując relacje wzajemne, kompleksowo, uzależniając często działania w jednej dziedzinie od postępów państw partnerskich w realizacji warunków w innej (tzw. polityka warunkowania), poprzez współpracę z innymi podmiotami międzynarodowymi (multilateralizm) oraz przy respektowaniu norm prawa międzynarodowego ${ }^{22}$. Zasady te stoją jednak niekiedy w sprzeczności z interesami państw członkowskich UE, kierujących się w swojej polityce bardziej realizmem politycznym, aniżeli liberalizmem.

Nieuczciwe byłoby jednak pominięcie, w ocenie efektywności polityki Unii Europejskiej czynników zewnętrznych. Relacje palestyńsko-izraelskie należą bowiem do jednych z najbardziej skomplikowanych w skali świata. Toczący się od 1948 roku konflikt między tymi stronami, jest jednym z najdłużej, obok konfliktu indyjsko-pakistańskiego o Kaszmir, trwających konfliktów międzynarodowych. Rozwiązania wymagają trudne obiektywnie problemy: obszar, na jakich ma być utworzone państwo palestyńskie, w tym status Jerozolimy, do której obie strony roszczą sobie prawo, niewielka ilość źródeł wody pitnej, problem uchodźców palestyńskich ${ }^{23}$.

Przyszłe działania Unii Europejskiej wobec Palestyny zależeć będą więc zarówno od czynników wewnętrznych, jak i międzynarodowych. Borykająca się z bardzo poważnym problemem deficytu finansowego oraz przywództwa politycznego UE w jeszcze mniejszym stopniu niż dotychczas zdolna jest do prowadzenia spójnej polityki zewnętrznej. Ponadto, największym atutem działania Unii były dotąd instrumenty ekonomiczne, natomiast w dobie kryzysu finansowego możliwość stosowania tego środka oddziaływania spada. Trudno przewidzieć jak ukształtuje się w ciągu najbliższych lat układ sił na Bliskim Wschodzie. Część państw arabskich przechodzi poważne zmiany wewnętrzne, których jednak wynik, w końcu 2011 roku, trudny jest do przewidzenia.

22 Szerzej nt. tożsamości międzynarodowej UE zob. np. J. Zając, op. cit., s. 57 i n.; J. Raux, L'identité internationale de l'Union européene, Paper presented to group on Federalization of the Union: Myths and Realities?, Contributions to the meeting of the 6-7 July 2000, Intergovernmental Conference 2000, http://www.consuniv.org/docs/Raux6juillet.doc; Ch. Damro, Building an International Identity: the EU and Extraterritorial Competition Policy, ,Journal of European Public Policy” 2001, vol. 8, no. 2, s. 208-226; I. Manners, R. G. Whitman, The „,Difference Engine”: Constructing and Representing the International Identity of the European Union, „Journal of European Public Policy” 2003, vol. 10, no. 3, s. 380-404. Wcześniejsze rozważania tych autorów na temat tożsamość międzynarodowej Unii Europejskiej zob. I. Manners, R. G. Whitman, Towards Identifying the International Identity of the European Union: A Framework for Analysis of the EU's Network of Relationships, „Journal of European Integration" 1998, vol. 21, no. 3, s. 231-249.

${ }_{23}$ Szerzej nt. problemów bezpieczeństwa na Bliskim Wschodzie zob. np.: J. Zając, Bliskowschodni kompleks niestabilności i bezpieczeństwa, w: red. R. Zięba, Bezpieczeństwo międzynarodowe po zimnej wojnie, Wydawnictwa Akademickie i Profesjonalne, Warszawa 2008, s. 361-395; Problemy bezpieczeństwa na Bliskim Wschodzie, red. A. Potyrała, J. Raubo, Wydawnictwo WNPiD UAM, Poznań 2010; Bliski Wschód coraz bliżej, red. J. Danecki, S. Sulowski, Dom Wydawniczy ELIPSA, Warszawa 2011. 
Iran, zgodnie z opublikowanym na początku listopada 2011 roku raportem MAEA bliski jest wyprodukowania broni jądrowej. Coraz większą pozycję w regionie zyskują Turcja oraz Chiny, spada natomiast pozycja Stanów Zjednoczonych. Najbliższe lata zmienią dotychczasowy porządek na Bliskim Wschodzie, w którym przyjdzie działać Unii Europejskiej.

\section{Summary}

\section{The European Union's attitude to the idea of a Palestinian state}

The European Union is an important actor in the Middle East Peace process. It has supported Palestinian aspirations for creating an independent state. In 1980, the European Community already underlined that peace in the Middle East should be based on 'recognition of the legitimate rights of the Palestinian people'. Since the 1990s it has supported the state-building process in Palestine. It is also the biggest provider of financial aid to the Palestinian people. However, EU policy is not coherent, which was clearly visible on 31 October 2011, when UNESCO members voted on Palestinian membership. Eleven EU-member states voted 'yes', five of them were against, and eleven members abstained.

The purpose of the article is to analyze EU policy toward the concept of a Palestinian state, EU activities and their effectiveness. 
